\title{
Interviews
}

\section{6o-Minute Conversations with Jesuit History Series} "I think that I give thanks every day - and if I don't, I should confess that sin-for the fact that I was born into the post-Vatican II church": A Conversation with David M. Neuhaus, S.J.

David M. Neuhaus, S.J.

Saint James Vicariate for Hebrew Speaking Catholics in Israel neuhaussj@gmail.com

\begin{abstract}
In October 2016, Rev. David Neuhaus, S.J. delivered at the Boston College Center for Christian-Jewish Learning's Fifth Annual John Paul II Lecture in Christian-Jewish Relations. He is the patriarchal vicar for Hebrew-speaking Catholics in Israel. He is also the coordinator of the pastoral care for migrant workers and asylum seekers. At the occasion, Robert A. Maryks, the editor of this journal, interviewed David about his Jesuit and scholarly career. This is the second of a series of 6o-Minute Conversations with Jesuit History. What follows is an edited transcription of the interview that was videotaped at Boston College in October 2016 (https://www.youtube.com/watch?v=vFcIq38m9MI).
\end{abstract}

\section{Keywords}

David Neuhaus, S.J. - Institute for Advanced Jesuit Studies at Boston College 6o-Minute Conversations with Jesuit History Series - Christian-Jewish Relations

MARYKS: Welcome to Conversations with Jesuit History. I'm Robert Maryks of the Institute for Advanced Jesuit Studies and of the History Department here at Boston College. Our guest today is Reverend David Neuhaus, S.J., who is a 
patriarchal vicar for Hebrew-speaking Catholics in Israel and coordinator of the pastoral care for migrant workers and asylum seekers. Welcome to Boston College, David.

NEUHAUS: Thank you very much.

MARYKS: David is visiting Boston College to deliver the fifth annual John Paul II Lecture in Christian-Jewish Relations, correct?

NEUHAUS: Correct.

MARYKS: Now, David, you were born in Johannesburg, South Africa, in a Jewish family, and some thirty years later, you entered the Society of Jesus. Would you please explain to our audience how it happened?

NEUHAUS: So indeed I was born in 1962 into a German Jewish family. I was first generation born in South Africa-my parents fled Nazi Germany in the 1930s - and growing up as a Jewish child received a rigorous Jewish education. We were not a practicing family, but our Jewish identity was very important. I think, like many Jews in the world today, the primary basis of our Jewish identity was culture and history rather than religious practice. But we received a good Jewish education.

At the age of fifteen, my parents decided to send me off to Israel, I think more motivated by the rather grim circumstances in South Africa in the mid1970s. But that was facilitated by a school program, so we went off togethera big group of kids from the Jewish day schools in South Africa-to spend a number of months in Jerusalem. The idea was to draw us even more firmly into the Jewish community by giving us an even better Jewish and Hebrew education and certainly an identification with the state of Israel.

And I went kicking and screaming. I was not really interested in all of that, as were not many of my friends. At that time, I was very interested in European history, particularly the history of Russia before the Russian Revolution. So one of the projects I had was to run away from the boarding school where we were. That could happen on a Saturday Shabbat afternoon, when everybody was after the Shabbat meal and going for a rest, and I made a beeline for the gate and went off to find a Romanov princess who lived on the Mount of Olives as a Russian Orthodox nun. I was going to interview her. That was the plan.

I arrived at the Russian Orthodox convent on the Mount of Olives only to find that this princess was already very aged, already in a coma, unable to respond to questions. But her assistant, another nun, said, oh, you're interested 
in that time period? We have another very elderly sister in a church just down the road. Go and see her. She's completely clear and able to express herself. And off I went and spent about two and a half hours in the company of a paralyzed eighty-nine-year-old Russian Orthodox sister, who was an aristocrat in her origin. We spoke about Russian history, and it was absolutely fascinating. I was just delighted with the way things went, what she told me, the information, the anecdotes.

I left her after about two and a half hours and went back to boarding school, and on the way home, suddenly thought to myself, wait one second, that person I just met was the most joyful, radiant person I've ever met in my life. And then I immediately said that's not possible. A paralyzed eighty-nine-year-old nun as the happiest person I met? Can't be.

So the next Saturday, I ran away again from boarding school at the same time and went back to see her and said, look, I'm not here to talk about Russia. I have a burning question that is really intriguing me. How come you're so happy? You have no reason to be happy. How come you're so happy? And after much hesitation - she knew I was Jewish, she knew certainly I was fifteen years old, she wasn't so eager to talk about that part of her life to someone like me-but I was so insistent that finally she burst out, I'm happy because I'm in love, and then slowly but surely started speaking about Jesus, and suddenly he was there in the room. It was not a mystical experience or a vision, but just such an authentic witness to who he was in her life that he was simply rendered present in her joy. And I've never doubted since. I mean, it was a moment of encounter with him. I did not particularly believe in God. I'm not sure if I did or didn't, but he certainly didn't interest me.

I then went back to my regular life, and he became part of that life. And when I went at the end of the school year to see my parents, I said, Mom, Dad, I went to Jerusalem not particularly convinced that God exists. Now I know he does, and he has a son called Jesus Christ. And I want to be a Christian.

My parents, who were quite shocked, looked at me and said how can you go and join them after everything they've done to us? So I said, oh, I never thought about that. I'm thinking of Jesus and me, not what his supposed disciples did to Jews through the centuries. So I said to them, ok, let's relax. We'll take some time about this. I tell you what-we'll make a deal. I'll not do anything for ten years. I was fifteen. Until the age of twenty-five, I will make no formal move to become a Christian. But if this remains true when I'm twenty-five, you'll accept. And my parents did. They probably said to one another afterwards, oh my God, today he wants to be a Christian. Tomorrow he'll want to be a Buddhist. Let's hope by the age of twenty-five, he's got some sense in his head. 
So I went back to Israel, did my studies, remained in close contact with the Russian Orthodox church, but with this burning question of how is it possible that people who follow Jesus could behave this way to the Jews-and posed this question to the sisters in the Russian Orthodox church. The answer I got was not a satisfactory one. The answer I got was, well, the world's a bad place. Bad things happen in the world. You want to be safe, you want to be in the embrace of Jesus always, stay in the liturgy. The liturgy is God's kingdom on earth. I kind of did agree that the liturgy was very close to God's kingdom on earth but didn't quite agree that if I stayed in the liturgy, that would be enough, that would be some kind of security with regard to the question of my parents. Certainly I had no answer for my parents.

So I continued to look and started to go beyond the borders of the Russian Orthodox church until sometime in the very early '8os, a few years later, I met the first Jesuit that I ever met in my life. He was also the first Catholic priest I met-in fact a Jesuit whose origins go back to this area. He was from New England. His name is Father Peter Du Brul. He's still alive. Many, many years ago, in the very early '6os, he made a radical option for the Middle East, first through Baghdad, through Iraq, which was a part of this province here in New England, and then afterwards an integration-a full integration in the province of the Near East. He had been living in Palestine since 1975, in Bethlehem.

So I met him. I had become involved in interfaith dialogue through a very close Muslim friend, who brought me in as his Jewish friend into the dialogue and met Peter. And Peter really impressed me. He impressed me because every time I had a question, he had about ten or twenty questions more-never gave me any clear answers. That seemed a lot more real than giving firm answersand through Peter became exposed to the Catholic Church.

The person who again didn't give me an answer but who was very important in bringing me into some kind of peace with my parents' question was getting to know the figure of Pope John XxIII. I'm almost convinced that his questions that led him to convene the council were very close to my parents' questions. How could that happen? And his willingness to dialogue with the world out there that was not perceived as dark and evil but a world full of opportunity for dialogue and growth really attracted me.

So between Peter and Pope John XXIII and slowly getting to know the small Catholic community in Jerusalem, the ten years passed. I was a student at Hebrew University. I finished my вA and my master's degree, then had to deal with the Israeli army and had the wonderful opportunity of spending a period in prison as a conscientious objector, which was my first taste of what it might mean to be on a long retreat. And when I came out of prison, already by then 
catechized, because I had met the Hebrew-speaking Catholic community, the community that I now lead, and the rule was no baptism until real profound discernment and at least two years of getting used to what that might mean in your life.

So when I came out of prison, I was ready and was baptized in 1988, on the $8^{\text {th }}$ of December, by Father José Espinosa, another Jesuit-Nicaraguan Jesuitwho was working in Jerusalem. Peter had sent me to see José, and José again impressed me profoundly with his willingness to ask questions-and difficult questions. José was more in contact with the Jewish world, Peter more in contact with the Palestinian world. Their friendship also impressed me- the fact that they had made two very different options for solidarity, and yet despite these two opposed options, they maintained a dialogue and a friendship all through those years.

As soon as I was baptized-so that was two years after the ten-year period had ended, waiting for my parents-I went to José and said I'm sure it's obvious to you I feel a real deep call—a vocation — to life as a Jesuit. And he looked at me, and he said you're crazy and you're much too fast. Anyway, according to the Constitutions of the Society of Jesus, we don't accept neophytes, so you have to wait three years.

So I said, oh, great. That'll give me the time to come out of the closet as a religious to my environment, to my family, friends. I did my doctorate at Hebrew University during those three years, so the time was full of interesting encounters. And then together with Peter, traveled to Egypt to meet the provincial of the Near East province. I was very determined that I wanted to enter the province of the region.

I didn't take into account- the provincial drew my attention to that immediately—that I, as an Israeli Jew speaking Arabic — I spoke Arabic — would have enormous difficulty integrating into a province made up of Egyptians, Syrians, and Lebanese. I thought that would be a wonderful adventure, and he thought it was an impossibility. So it was he who proposed that I apply to the New England province and do my training in New England and then see where that would lead.

But just before I came to New England, after I'd been accepted as a candidate, he wrote and said no, no, you should integrate into our province. Go off to New England, spend a time of discernment there-and that time I spent at Boston College teaching in the political science department, 1991-92. August '92, I entered the novitiate in Jamaica Plain for the New England-well, not for the New England province, but that was the New England province novitiate—but for the Middle East province. 
The provincial came to visit me, and then the decision was made that in second year of novitiate, I would be introduced into the province of the Near East. So I went back to the Near East and lived in Egypt for two years, becoming a part of the province of the Near East and getting to know my fellow novices. We had a wonderful time together. We were four. I'm the only left. Wonderful novice master in Cairo. And then the year after novitiate, having a year to teach in our high school in Cairo-Collège de la Sainte Famille. That was also the year to learn French. I was teaching in Arabic religion and then English.

MARYKS: In the novitiate, what language did you use?

NEUHAUS: Arabic.

MARYKS: Arabic?

NEUHAUS: It was completely Arabic, yeah. The three other novices-two Egyptians and a Syrian, our novice master was an Egyptian — and everything was in Arabic. I had perhaps less difficulties with the Arabic of Egypt than with the culture and American of Boston. There was many more cultural-

MARYKS: You mentioned that yesterday during your lecture, right-your difficulty with the English-

NEUHAUS: With the understanding there. The Catholic very Irish culture of the Society of Jesus in Boston was really something that I had to discover little by little, whereas the culture of the Arabic-speaking church was something that I knew already well and felt comfortable with. And so it was a wonderful time-and then a year of teaching in our college in Cairo and studying French at that time. I was then sent at the end of that year, which was considered a year of regency, to do three years of theology together with other Middle Easterners - we were about a group of fifteen - in Paris at the Jesuit [inaudible] at Centre Sèvres. And those were three very rich years intellectually.

At the end of those years, the new provincial by then said to me, please go back to Jerusalem and try and find out what the local church would expect of a Jesuit coming back to work in Jerusalem. I got an absolutely unanimous answer that what the local church would like is someone who can teach scripture. So although my doctorate in Hebrew University was in political science, my provincial made the very wise decision to send me to Rome to do a license in scripture at the Biblicum.

That was really the discovery of a second vocation, perhaps a third. The first vocation to be a Christian, the second vocation to be a Jesuit, and the third 
vocation to teach scripture, which during my studies I discovered that I really loved-and then went back to Jerusalem at the beginning of the year 2000. I was ordained a deacon in the Biblicum by Father Giuseppe Pittau, who was then the delegate for the International Roman Houses and then became a bishop. He was the delegate when I entered the Society and then became a bishop in the congregation for education. He came to the Biblicum to ordain me and then went back to Jerusalem and a few months later was ordained a priest.

Two weeks before I was ordained a priest, I began teaching in the Roman Catholic Seminary in Beit Jala alongside Bethlehem, a job that I held for nine years, as my principal work teaching scripture in Arabic, both in Beit Jala Seminary and in Bethlehem University, where I also started to teach courses on Judaism and Hebrew. And those were wonderful years - wonderful years, very difficult for the country. I started teaching in August. In January 2001, it was forbidden for Israeli citizens to pass into Bethlehem, Beit Jala. So those were creative years of thinking how am I going to get around being forbidden to go in and continue to teach? Wonderful relationships established with the local clergy.

And then in 2009, I was appointed to the positions that you've just mentioned at the beginning of this interview. I was named to be the episcopal vicar, the patriarchal vicar, for the Hebrew-speaking community, a position that had been created in 1990. I had two predecessors. And I am the first person to hold that job as a full-time job, so the vicariate has been able to really undergo a lot of important changes, also widening its vistas and taking into account the tens of thousands of migrants who live in Hebrew-speaking society in Israel. So that's my principal job now.

MARYKS: oK. Well, thank you. Now, my second question-actually, I would like to go back to some things that you mentioned in this brief account of your life and vocation. Do you have siblings?

NEUHAUS: Yes. I have one brother three years younger than I am-thanks be to God in terms of our parents. He is married, with two children and a grandchild. [laughter]

MARYKS: How did they react to your decision to become a Christian and then a Jesuit?

NEUHAUS: I've been very, very blessed-blessed by God and blessed by my parents-you know, having the parents I have. Taking the ten years was a real time for them to feel a little bit more at ease with this very strange journey of their son. By the time the ten years had passed, the family was reconciled that 
this was part of the family story. By the time I entered novitiate, my parents already started to understand that this was truly my way. I'm not saying that they fully understood what that might mean in terms of celibacy, obedience, poverty, but they felt already that they could live with it.

In fact, I'll tell this little anecdote, which is very nice. When I went to see my parents before entering novitiate to try and explain to them what this would all mean in my life, I was sitting one day with my father. My father, who passed away last year, was a motor mechanic. So he said, you know, I fix the cars of some important Christian leader. Do you want me to invite him for dinner? So I said sure. Yeah, bring him over. And when this man arrived, I came down to meet the man. And he immediately, before I could say anything, said your father told me that you were a conscientious objector. I work in South Africa with conscientious objectors. What led you to want to be a conscientious objector?

So I started to speak. And then at a certain point, I said, and for me it's perfectly clear that Jesus was nonviolent. And he turned white, looked at my father and then at me, and he said Jesus - what is Jesus for you? So I turned to my father and said, what, you didn't tell him that I'm a baptized Catholic? And my father gave a little smile and said, no, I didn't tell him. So he said, oh my God, you're a Catholic? Oh. And then I said to him, my father said you're some kind of Christian leader. What are you exactly? And he said, well, you've probably never heard of us, but I am the regional superior of the Jesuits in South Africa. And I looked again at my father. My father was chuckling to himself-set up this whole meeting with — so yeah, my parents began to feel more comfortable.

When I took my first vows here in New England at St. Ignatius Church, my parents insisted on sending my brother to be present as the representative of the family. They were not able to come. And when I was ordained a priest in 2000, my parents came to the ordination. I then asked the man in charge of the ceremony — the cérémonier — of our diocese whether I might be able to ask my father to do the first reading in Hebrew at the ordination. And the cérémonier said, absolutely not. Your father's not baptized. And I said, you know, it's my ordination, and it is my father. Perhaps ask the patriarch, our archbishop—ask the patriarch.

So a few days later, the patriarch saw me and he said, Father David, you're a real saint. I said, oh, I'm certainly no saint. Why do you say that? And he said, because if I had received the response you received from the cérémonier, I would have punched him in the nose. Of course your father can do the first reading. And so my father did the first reading in Hebrew, and they were a central part of the celebration, and came to all the first Masses and really felt very much included within the celebration. Yeah, it's been a real grace. I know 
a lot of people who have had terrible, terrible consequences to the decision to change their religion-Jews who became Christian who lost all contact with their families, who sat periods of mourning for them, whereas I have had this wonderful grace that I have very good relations with my parents and-

MARYKS: Beautiful.

NEUHAUS: —we talk about it a lot.

MARYKS: There's a special relationship that Ignatius of Loyola, the co-founder of the Society, had with Jerusalem. Did it play any role in your vocation?

NEUHAUS: Well, it did in a kind of vicarious way. Why? Because Father Peter Du Brul, whom I mentioned before, who is one of-he's the first priest I met, certainly the first Jesuit I met, and a very important influence on my early life as a Christian and a priest, was very, very intrigued by that connection between Ignatius and Jerusalem and has spoken about it a lot. I've listened over the years and really been convinced that Jerusalem was a very special place for Ignatius and perhaps should be for Jesuits. Maybe it's not enough a special place.

Of course, that leads me to think what could be the special contribution of Jesuits in Jerusalem in the local church, and I think that too is very, very clear. It's the gift of the Spiritual Exercises but also the gift of discernment-a discernment that we need to have at the base of all of our reflection as a church on who we are, what we are doing, in order that we are not so much led by events and the discourse but that we can be really people who are showing a way to go through the kind of complicated mess in which we live. We have had great Jesuits passing through the Holy Land, but perhaps we haven't taken seriously enough the fact that Ignatius was really called to the Holy Land.

MARYKS: Yeah. Now Ignatius and the first companions-their desire was to go to the Holy Land to work with Muslims.

NEUHAUS: Yeah.

MARYKS: Would you see any special role that the Jesuits should play in the Holy Land in-

NEUHAUS: You speak as a very modern Jesuit and you say "to work with Muslims." Ignatius was driven by a desire to convert the Muslims. [laughter] 
MARYKS: Right.

NEUHAUS: I think that dialogue with Islam, dialogue with Judaism plays a part in the mission of the Society, and that's very important. Again, what I think could be a very important role for the Jesuits - and some have played that role, but as driven individuals - I'd like to see something a little bit more-

MARYKS: Institutional?

NEUHAUS: - discerned by the Society itself in terms of offering the Spiritual Exercises to a church in deep crisis and offering the Spiritual Exercises so that the church can more clearly discern not only its identity and mission but also the very important role the church has as an observer of what's going onand not just an observer, but an active participant in what's going on. I think a stronger presence of the Jesuits is not only something that I would desire, but I've heard it repeated by the church in the Holy Land, by the hierarchy of the church, the faithful of the church, who really often ask, where are the Jesuits?

We do have a strong presence in Lebanon, a very appreciated presence in Syria in the midst of this terrible crisis that we are going through. I think some of the most sane Christian discourses have come out of the Society-in particular Jesuits who are working in Damascus, Aleppo, Homs. And of course we're also present in Egypt.

Our province now - and this is absolutely new, happened just a few months ago- - has now taken responsibility also for the community in Jerusalem and in the Holy Land. I hope that that will lead to a more serious reflection not only on the important work of the Biblicum in Jerusalem, but also a reflection on how can the Jesuits be at the service of the local church in the Holy Land and then of course throughout the Middle East.

This is a time when discernment and a real formulation of discourse that is particular - that is not being driven by existing discourses. We need creativity. And I think that the society has been creative in the past in so many situations. That kind of creativity is really a dire need in the Middle East today.

MARYKS: David, had you entered the Society of Jesus during the tenure of Ignatius of Loyola, Diego Laínez, and Francisco de Borja, you would have been received with open arms. But that would not have happened if you decided to enter sometime between 1573 and 1945 -

NEUHAUS: ' 46. 
MARYKS: — 1946, yes, because you would be considered a candidate of Jewish origins, and you would not be allowed to enter, right? How do you feel about this historical development?

NEUHAUS: First of all, I always feel it's important to stress that that impediment to enter was an impediment of purity of blood, and it was not only Jews, it was also Muslims who could not enter. So anyone of Jewish or Muslim blood was not welcome in the Society without special dispensations. There always were people of "impure blood" who entered the Society.

I think that this is part of our history as Jesuits that we need to confront, but of course not just as Jesuits. This was part of a Christendom that really incarnated something that was presented to me-the first time that I had to think about it seriously was when my parents said, how can you join them after what they've done to us?

I think that I give thanks every day-and if I don't, I should confess that $\sin$-for the fact that I was born into the post-Vatican II church, a church that is trying to come to grips with that heritage. I think it would have been much more difficult for me, hearing my parents' searing question, to enter a church that had not started to come to grips. Of course, coming to grips does not mean we wipe out the history, but that reflecting on the history, we start to develop our identity, our discourse, and our mission in terms where that becomes impossible. We can no longer think in those terms. We are horrified that such things went on. I think it's particularly gratifying to hear modern Catholics express their almost disbelief that certain forms of Christian discourse existed in the pre-Vatican II era.

So I'm constantly aware of that. I feel that I am called by Jesus. I am an integral part of the church, but at the same time have a real responsibility to be conscious that we are coming from a place where we must never sink back into that place. We are inheriting a discourse that must never become our discourse. So there's a kind of standing on one's guard all the time, both that I never express myself in those terms, because I am part-it's a tradition I've adopted and in which I was formed - but also hearing others, to be able to point out and say that's who we once were. That's who we are not anymore. So yeah, it's something that I think we need to be constantly conscious of.

What I am also very conscious of is that that must not become something set in stone, so that we are not aware that those kinds of attitudes, that kind of discourse, can somehow transform itself and re-manifest not towards Jews but towards others. Whether those others are Muslims or women or homosexuals or wherever that discourse might become a discourse of contempt, we must be aware and learn from our past. 
MARYKS: Did you ever experience any discrimination within the Society of Jesus because of your origins?

NEUHAUS: I never experienced any discrimination, but I certainly was witness to discourse that made my hair stand on end [laughter] — sometimes in homilies, when we are not aware enough of how the discourse we speak that seemingly is a literal reading of New Testament texts can really vehicle a contempt. I'm thinking of homilies that I sometimes hear about the Pharisees or the Jews who opposed Jesus. But I've also had to learn that the freedom that I might have in my discourse is not always a freedom shared by others.

I remember sitting once at Boston College in the refectory. I had just arrived. I was not a Jesuit yet - a candidate to the Society. Many of the people in the community did not know my story. Although they knew I came from Israel, they didn't know I was a Jew. So I was sitting with a group of young Jesuits, one older Irish Jesuit present, and sharing with them my meditations on the present Israeli regime. This was in 1991. We were going through very difficult times - the first intifada was really being violently suppressed — and I shared my horror at what my government was doing to Palestinians.

This old Jesuit, who was sitting at the table and I'm sure would never have dreamed of expressing what he expressed had I not been criticizing the Israeli government-at the end of what I had to say, he said it's really terrible what the Jews are doing to the Palestinians. But you know what really bothers me more? The way the Jews talk about the Germans. The Germans always treated the Jews very well. I cannot accept the lies they spread about the Germans.

My mouth fell open. I immediately recognized that this man would never have said that had I not led him to believe that I, like him, had a very negative opinion of Jews - which of course is not true for me, but that's what he understood. I had in a certain sense betrayed him, so he lowered his defense and spat out something which he thought would be intimately appreciated.

Of course, I was absolutely horrified. And I stood up with my mouth open, and I didn't know what to say-until I suddenly just blurted out: "Father, not right now because I need to leave, but one day you'll tell me what happened to my relatives, who were wiped out by the Nazis." That poor man could never look at me again. I had really profoundly betrayed him. He thought I was a fellow traveler, and I turned out to be one of them, as he found out afterwards.

So I've come to realize that, yeah, there is still an undercurrent there that we must be aware of, and sometimes it's an unconscious undercurrent that can come out in preaching or the expression of opinions. Then again, the answer is not to be reactive but really to help us as a body purify our language, purify our thought, and move into that new place that was opened up by Cardinal Bea, 
by John XXIII, by a community of saints who realized that we are locked into a system of oppression that betrays our identity and our mission.

MARYKS: You fell in love with scripture, you mentioned before. Do you think that scripture can become a source of anti-Semitism?

NEUHAUS: I think there's no doubt about the fact that scripture, because it is interpreted scripture, can become the source of many different discourses of oppression and hatred and refusal of the other, including Jews. This is not an opinion. This is history, as we see how scripture was read and misread over the centuries. But that is part of the wonderful enterprise of exegesis-really trying to encounter Jesus in the word, and here are the echoes of his message all through scripture. I think that's a particularly Christian challenge-to read scripture from Genesis to Apocalypse always hearing Jesus opening those scriptures for us - of course perfectly aware that the Jews have a parallel reading that we are called to appreciate and respect, where Jesus is not the teacher but the rabbis are the teacher.

So again, yeah, I'm perfectly aware that scripture can be a poison and a dynamite - a destructive dynamite - but engaging in that enterprise of interpretation is for me a passion, and then teaching. I'm not so much a scripture scholar who sits in a little room and writes articles-

MARYKS: Manuscripts and-yeah.

NEUHAUS: No. I love scripture because I find it is a way to bring Jesus into the lives of seminarians and lay people and children. And interpreting scripture really connects us with that language that we are called to adopt as our own.

MARYKS: Now, you mentioned Cardinal Bea, the German Jesuit who was the architect of Nostra aetate. He was rector of the Biblicum, so he was a biblical scholar. Then also Cardinal Carlo Maria Martini was a biblical scholar, then archbishop and cardinal of Milan, an Italian Jesuit. And both of them obviously had a special relationship with the Jewish people, right? So where do you see a connection between being a biblical scholar or someone who teaches scripture, just like you, and that relationship to-

NEUHAUS: Again, I think that there, there is something that's absolutely crystal clear, and that is the awareness that the scriptures we read are written by a people. This is the language, experience, and stories of a people. What I am very aware of is that all peoples who become Christian are called to be grafted 
into that people. The grafted in of course is a citation from Romans 11, where Paul talks about the two olive trees and that the gentiles from the wild tree are called to be grafted into the domesticated tree-so that in a certain sense, Jesus and those that follow him are opening up Israel to all the gentiles. So there is an intimate connection between our identity and our mission and the people of Israel — an identity and mission that the people of Israel don't always feel comfortable with. That becomes an incredible challenge to respect their discomfort, all the while insisting that this is who we are.

The latest declaration or the latest meditation coming out of the Holy See about the fifty years of relationship between Jews and Christians in the light of Nostra aetate that was published in 2015 I think is a masterpiece in terms of really underlining our identity and mission so much defined by our being grafted into Israel and the discomfort of Jews, that in a certain sense, in our own identity we don't respect the borders that they feel are so important between Jews and Christians. So yeah, I think that there is no way to be Christian without constantly meditating upon who is Israel, because that's the people into whom we are grafted.

For me, this is very important in terms of the language that we are called to speak, the language we are called to learn. We don't only read the Bible to learn the stories or to know the great figures. We read the Bible in order to learn how to speak about God and how to speak about ourselves. It's a real school of language, and I think that we are called to adopt that language in our being Christian. And it's a language where much of it we share with the people of Israel. Of course, there are very important places where we wouldn't agree on how to interpret the language that we both use.

MARYKS: Historians debate about distinctive identity of Catholics or Christians of Jewish origins and specifically of Jesuits of Jewish origins. Does your own ethnic and religious background make your Jesuit identity different or special?

NEUHAUS: That's always a hard question to answer, because I have my identity. How do I know how other Jesuits interact with their identity? I mentioned that we have a very interesting little group of scholars who come together once a year-not Jesuits but Christians from different churches. It's an ecumenical group. It's a group where there are Catholics and Orthodox and evangelicals and messianic Jews.

We come together to talk about our identity and to kind of look into this question about is there anything particular about our identity as followers of Jesus? And we are all—the Orthodox, the Catholics, the evangelicals, and 
the Messianics - we are all Jews. OK? So it's a very interesting forum that was founded a number of years ago in Helsinki. One of the founders is a Dominican priest. The other is a Messianic rabbi. And they brought in a small group, all of us engaged in research and writing and teaching, to really look into this question of is there anything that holds us together as Jews in the church? Again, it's the church in its broadest definition of all who believe in Jesus.

I'm not sure that we have a very, very firm answer. One of the things that is often jokingly applied to the Jews is you have two Jews and five opinions. So in our little group of fifteen or twenty, we have fifteen or twenty and eighty opinions about this very subject - that is, what is the particularity of being a Jew in today's world who has found Jesus, met—encountered Jesus - and decided to follow Him? Yeah, I don't have a very clear sense. Of course, there is a sensation that my Jewish identity is very important to me and that makes me different from gentile Jesuits. But are there really gentile Jesuits out there? Do they feel themselves as gentile Jesuits, or is there something very particular in being a Jesuit of Irish origin or Egyptian origin? I'm not sure. I don't spend a lot of time reflecting on that.

MARYKS: OK. Now when we were talking about Bea, another thing that came to mind was that the group that was collaborating with Bea in hammering out Nostra aetate, most of them were-

NEUHAUS: Jews.

MARYKS: - Jews converted to Christianity. How would you explain that?

NEUHAUS: Well, I think the enormous sensitivity —of course, there again, there is a long history, and it might be very much a stereotype, of Jews who became Christian and used a kind of language of, oh, once I was lost in Jewish superstition and now I've found the truth. Before the Shoah already, but certainly after the Shoah, there is a different kind of Jew who discovers Jesus, and that's a Jew who is not willing to give up his Jewish identity, who is proud to be Jewish.

I say even before the Shoah, because when I think of somebody like Edith Stein, who died in the Shoah, I think that she was very aware of her Jewish identity and not willing to give it up. ok? And others like her-Raissa Maritain, the wife of Jacques Maritain, would be another who was, as a Christian, very, very determined that belonging to the Jewish people was a blessing. I think also of the Ratisbonne brothers. This is something born in the nineteenth centurymight have something to do with the new concept that is born sometime in the seventeenth century that the Jews are not simply a religion, like Christianity 
or Islam. The Jews are a people. And history is a very important part of the identity of that people.

Yeah, when we move into the modern period, when we think of people like John Oesterreicher, Bruno Hussar, and others who were instrumental in working with Bea to hammer out the wording of paragraph four of Nostra aetatethese people were very conscious of their Jewish identity, proud to be Jews, and of course after the Shoah also very much aware that the Nazis made no distinction between baptized Jews and Jews who were not baptized. There's a beautiful book written by a Pole about the three parish churches in the Warsaw ghetto that continued to serve the Jewish Catholics when the area was turned into the ghetto and how then afterwards they were all shipped off to the death camps, like everyone else.

So I think that there is a growing awareness over the centuries of a shared Jewish destiny, and baptism does not alter that. That might not have always been true. There are famous conversos of the medieval period who turned into some of the worst opponents of the Jewish communities-Pablo Cristiani and others. But in modern times, I think that there is a remarkable movement of Jews who have encountered Jesus and who insist very, very much that there is a vocation to be a Jew who has encountered Jesus within the Jewish people.

MARYKS: The name of the Society of Jesus and its artistic representation in the Jesuit mother church in Rome, Il Gesù, is, it seems to me, intrinsically tied to Luke's theology of Jesus's birth, circumcision, and death. Indeed, January ${ }^{\text {st, }}$, eight days after Christmas, used to be the Society of Jesus's titular feast. But the new Jesuit liturgical calendar changed that-

NEUHAUS: To the $3^{\text {rd }}$.

MARYKS: To the $3^{\text {rd }}$ of January, right? What do you think about this change?

NEUHAUS: [laughter] Yeah, it doesn't sit well. It's the eighth day-the day of circumcision, that Jesus is named. That's scriptural. That's Luke 2:21. There is something solid there about rooting Jesus in his people. And I think that in much later centuries when decisions like that are made, there is a certain indication that we aren't any more reflecting out of a scriptural language and consciousness that roots us in the people of Israel.

So yeah, it's a problem for me. Of course, you are not only changing the date from the $1^{\text {st }}$ to the $3^{\text {rd }}$ of January, the whole reference to circumcision has fallen 
away. It's kind of embarrassing, with our puritanical sense that you talk about the circumcision and you immediately focus on a part of Jesus that you don't want to think about, even though that part of Jesus - that part of his bodybore not only for the years of his earthly life but as a resurrected Jesus - that part of his body still bears the sign of the covenant.

And so no, for me and in my community, we continue to call the $1^{\text {st }}$ of January the Feast of the Circumcision and Naming of Jesus. Together of course with the Maternity of Mary, together with the World Day of Peace, it remains the Feast of the Circumcision. So when we reach January the $3^{\text {rd }}$, and in our Jesuit communities we celebrate the name of Jesus, I always say, well, that's only symbolic. We have the historical rootedness of that feast on January $1^{\text {st }}$.

MARYKS: Also if you think of Rubens's paintings, in Il Gesù of Rome or Il Gesù of Genoa, it's very clear that that's the central message of-

NEUHAUS: Absolutely. And we have that in many iconographic representations. If you go onto our website, for the $1^{\text {st }}$ of January, which we certainly have very explicitly and clearly the Feast of the Circumcision of Jesus, there is a beautiful-I think it's a seventeenth-century icon from the Greek Orthodox church in Lebanon, where you see very distinctly the priest going to circumcise Jesus. No, no, that for us is foundational. And of course it would be a very nice sign. There is a Jesuit who has proposed this-Jean-Pierre Sonnet - this would be a very nice sign of re-inserting ourselves into our rootedness in the Jewish tradition by recalling that the $1^{\text {st }}$ of January is in fact the Feast of the Circumcision and the Naming of Jesus.

MARYKS: Well, let's talk now about some contemporary issues. The Society of Jesus is celebrating its general congregation. A new superior general has been elected a few days ago. What do you think about the Society of Jesus todayabout the directions it's taking or it should be taking?

NEUHAUS: I'm a small fish in the big pond to think about such big things. I am so much focused on where we are in the Holy Land and where we are in the Middle East. We know Arturo Sosa well, because he was the delegate for the International Roman Houses and thus somebody who came to visit us once a year who got to know our apostolate. Perhaps more importantly for your question, we were able to observe him. So I certainly think that he's a man of prayer and of humility, a man of great optimism. And I think that will help us, because I think it's very important now that we look around at the world and really ask 
again — that's a question that's never exhausted — who are we and what is our mission in the world?

Again, we all know that we're to a certain degree in a moment of crisis, a moment where we need to make important decisions-that crisis is a kairos moment to decide, as our numbers are reduced, as some of our institutions don't seem anymore to really reflect who we are as the society or who we should be as a church, we need to, to some degree, realign.

Now, of course, my immediate concern is my immediate sphere of activity, and that is in the Middle East. And I know that my own provincial, Father Dany Younes, our former provincial, Father Victor Assouad, who were delegates at the general congregation - in our own discussions in the provincial congregation, we had to elect them, which I attended in Lebanon - these questions are very big questions, and that is who should the Society of Jesus be at this moment of intense crisis in the Arab world? Who should we be face to face with our Muslim brothers and sisters? What is our role in the political disintegration of the Middle East as we know it? These questions for me are very important questions. Now we will see, with Father Arturo, and I think we need a generous dose of optimism to really believe that the society has a role to play in all of this.

The other question that is so important for the Holy Father, for the churchand I'm profoundly involved in it as well-is the question of population moving, the moving of population from place to place.

\section{MARYKS: Migration?}

NEUHAUS: Migrants. This is altering the face of the planet and really presenting such huge challenges to the rich countries that are more and more closing their borders, more and more becoming non-Christian in that sense, in my humble opinion. How can the church help these countries to realize-as Pope Francis insists, this is a richness that is coming our way and not something to be thrown away and rejected.

MARYKS: Now we're here at an institution-Jesuit institution. Do you see any particular role that Jesuit institutions-educational Jesuit institutionsshould play in the context that you just have described?

NEUHAUS: Absolutely, without any doubt. I think that not only this is part of our history, but this is part of the future and where we need to more and more emphasize our contribution. Education, whether it's university education, 
high school education, or any other form of education, for me is not only the moment to learn by rote tradition that is inherited, but to open up horizons of creativity.

So I think that this is a very important part of who we must be in the Catholic world and the world beyond the Catholic Church, and that is helping people to see how the horizon opens up. I think that we live in a time where the discourse is very much build walls to protect what we have. The Jesuits, I think, need to be a body that is saying no, no, when you build church, you pull down walls, you don't set them up, and how this can open up to unimagined riches.

So I think very, very important. I do not want to see any - myself and for my little small corner of the Jesuit world, I would not want to see any kind of withdrawal from the world of education. It's very important. Of course, we need a realignment of forces. We need to think creatively how to do that. We are a small number in all of our institutions. We have a very important university in Lebanon. And I think again I really depend on that university to be able to reflect creatively on the new situation in the Middle East, and that would extend to all our educational institutions, wherever they are.

MARYKS: And on that note, I would like to thank you very much for this interview. Thank you very much.

NEUHAUS: Thank you. 
